\title{
Status of Elementary Education in the State of Sikkim, India
}

\author{
Nar Maya Subba, Yodida Bhutia \\ Department of Education, North Eastern Hill University, Meghalaya, Shillong, India \\ Email address: \\ s.narmaya@yahoo.com (N. M. Subba),yodidabhutia@gmail.com (Y. Bhutia)
}

\section{To cite this article:}

Nar Maya Subba, Yodida Bhutia. Status of Elementary Education in the State of Sikkim, India. International Journal of Elementary Education. Vol. 5, No. 2, 2016, pp. 17-27. doi: 10.11648/j.ijeedu.20160502.11

Received: May 17, 2016; Accepted: June 1, 2016; Published: July 15, 2016

\begin{abstract}
The elementary education is the most essential foundation in the educational life of an individual. Without going through the Elementary level of education, individuals cannot proceed to the secondary and higher levels of education. The system of education is categorised into different level such as pre primary, primary, junior high school (Upper primary), secondary and senior secondary. It covers the primary education which consist of students of 6-11 years and upper primary level which consist of students of 11-14 years. The aim of this level of education is to make every learner of 6 - 14 year old to acquire foundation skills such as the ability to read and write with fluency, numeracy, comprehension, analysis, reasoning and social skills such as teamwork. Thus the present paper highlights the status of Elementary Education in the State of Sikkim, India in the following aspect like number of government schools, number of teachers, number of students, administrative, infrastructural facilities and problems.
\end{abstract}

Keywords: Elementary Education, Sikkim, India

\section{Introduction}

Elementary education is a fundamental right for the children upto the age of 14 years. It is through elementary education that every child can learn reading, writing and numeracy. In government schools the Central and State government provides free and compulsory education for every child from the age of 6 to 14 years. It provides free uniforms, shoes, bags, text books, exercise copy, rain coats and free mid day meal for the children.

Universalization of Elementary Education (UEE) is a constitutional provision and national commitment in India. Elementary education is recognised as a fundamental right of all citizens in India. The Government of India introduced $83^{\text {rd }}$ Constitutional Amendment Bill in Parliament in 1997 to make education a fundamental right of all children of 6-14 years (Srivastava \& Tomar, 2011). It signifies that "education is for all and not for a selected few. This concept accepts that education is the birth right of every child. This means all children belonging to the rich and the poor, living in town as well as in rural areas and in places which are accessible with difficulty have to be provided with facilities for elementary education. Therefore, it is recognised as a fundamental right of all citizens in India" (Thamarasseri, 2008).

\section{Education in Sikkim}

The system of Education in Sikkim also based on education policy of the Nation. To achieve the goal of elementary education, various interventions like Sarva Shiksha Abhiyan have been launched in the State of Sikkim in the year 2001. The objective of this intervention is to provide education to all children in the State by providing basic infrastructures. The educational structure in Sikkim is not much different from that in other States of India. Sikkim has four distinct stages in school education. These are the primary (I-V), upper primary or middle, commonly known as junior high (VI-VIII), secondary (IX-X) and senior secondary (XI-XII) stages. Prior to the primary stage, there is the preprimary stage. The age of entry to the pre-primary stage is $4+$ and to the primary stage, 5+. All government schools are affiliated to the Central Board of Secondary Education, Delhi (Seventh all India school education survey, 2002).

The medium of instruction in these schools is English. Right from the primary stage, English is taught as the first language, beside this there are many State languages, namely, Lepcha, Bhutia, Nepali, Limboo, Gurung, Rai, and Niwari is taught as a second language. However, Hindi is taught as a compulsory language from class IV to VIII and it's treated as 
a third language in these classes. At the secondary level, English is taught as the first language and the student can offer any of the State languages or Hindi as the second language (Annual Report, 2003-04).

\section{Objectives of the Study}

The major objective is to find out the status of Elementary Education in the State of Sikkim, India.

The minor objectives are:

(i) To find out the number of government schools for the last six years.

(i) To find out the enrolment of students at elementary level.

(ii) To find out the administrative aspect at government schools at elementary level.

(iii) To find out the availability of infrastructure at government schools.

(iv) To find out the problems of government schools at elementary level.

\section{Research Design}

(i) Method: In the present study descriptive method was used.

(ii) Population: The population of study includes headmasters and teachers of government schools upto elementary level. The total numbers of headmasters are 777 with 7,370 teachers in government schools upto elementary level in Sikkim.

(iii) Sample: The sample of study comprises 200 headmasters, 600 teachers, 04 officials of Human Resource Development Department, Government of Sikkim. Headmasters and teachers are selected by simple random sampling.

(iv) Tools: The main tool for collecting data was Questionnaire and Interview schedule. Questionnaire-I was prepared for Head of the elementary schools and Questionnaire II was prepared for collecting data from teachers of elementary schools.

(v) The Construction of tools.

The researcher constructed two tools i.e., questionnaires and un-structures interview schedule.

The construction of questionnaires was done in two phases:

Phase I. The researcher consulted various literatures with regard to elementary education. Then the blue print for questionnaire was constructed which had five dimensions i.e. development of elementary education, administration, academic, infrastructure and finance. Further components for Head teacher's questionnaire were selected such as number of schools, number of teachers, number of students, school land, administrative records, appointment of teachers, norms followed for admission of students, incentives, school management committee, library, Information and Communication Technology and Mid day meal. Components for teacher's questionnaire (Questionnaire-II) included questions regarding infrastructural facilities like school building, staff quarter, school compound, play ground, classrooms, drinking water, toilets, electricity connection and problems in the government school at elementary level.

Phase II. Items for each component were written to ensure it's appropriateness with the content for which it was prepared. After the questionnaire was prepared, the tool was submitted to experts to check the content validity. Accordingly corrections were made based on the feedback from expert. There were suggestions for deletion of repetitive and vague items. Then the tool was put on the try out to establish its validity and to check objectivity. The try out sample consisted of four Head teachers and six teachers of four government schools at elementary level in the State of Sikkim. After the response from the sample the tool was corrected, it was found that around five items were not appropriate and it was deleted. The final questionnaire for heads of school had 44 items and for elementary school teachers were 20 .

Un-structured interview schedule was used to explore in details the status of elementary education in the state of Sikkim from Human Resource Development Department Officials, Government of Sikkim. Six officials of Human Resource Development Department Officials were interviewed for the study.

(vi) Delimitation: The study was limited to headmasters, teachers of government schools upto elementary level and officials of Human Resource Development Department, Government of Sikkim.

\section{Results}

\subsection{Number of Government Schools at Elementary Level in the State of Sikkim}

The table and figure given below indicates the number of government schools at elementary level in the State of Sikkim from 2009 till the year 2014.

Table 1. Number of government schools at elementary level (2009-2014).

\begin{tabular}{llllll}
\hline evel of Institutions & $\mathbf{2 0 0 9 - 2 0 1 0}$ & $\mathbf{2 0 1 0 - 2 0 1 1}$ & $\mathbf{2 0 1 1 - 2 0 1 2}$ & $\mathbf{2 0 1 2 - 2 0 1 3}$ & N.A \\
\hline Lower-Primary & 146 & 12 & N.A & N.A & 370 \\
Primary & 280 & 365 & 365 & 57 \\
Primary (SSA) & 54 & 54 & 54 & 59 \\
Junior High Schools (UP) & 145 & 196 & 196 & 193 \\
Total & 625 & 627 & 627 & 620 \\
\hline
\end{tabular}

Source: Annual Report, Human Resource Development Department, Government of Sikkim, Planning and Monitoring Evaluation Cell Note: SSA- (Sarva Shiksha Abhiyan) UP- (Upper-Primary Schools) NA (Not Applicable) 


\subsection{Growth in Number of Schools at Elementary Level in Sikkim from the Year 2009-2014}

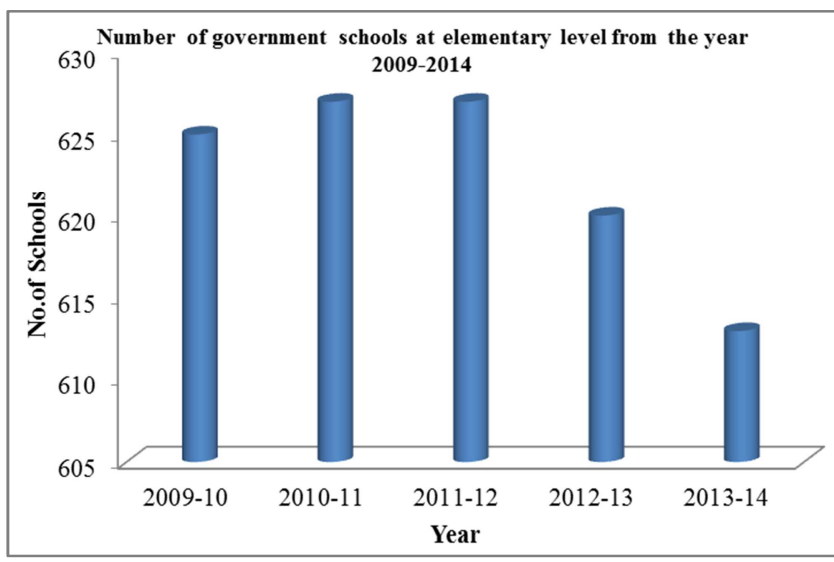

Figure 1. No. of government schools at elementary level.

From the above Table 1 and Figure 1 indicates that the number of pre-primary schools were 146 in the year 20092010 which was decreased to 12 in the year 2010-2011. The number of primary schools in the year 2009-2010 was 280 which was increased to 370 in the year 2012-2013. The numbers of primary Sarva Shiksha Abhiyan schools were 54 in the year 2009-2010 which was increased to 57 in the year 2012-2013. The number of junior high schools in the year 2009-2010 was 145 which was increased to 198 in the year 2011-2012. The total numbers of schools were 627 in the year 2010-2011 which was decreased to 613 in the year 2013-2014. It is mentioned by the Additional Director, Human Resource Development Department, Government of Sikkim that the numbers of schools were decreased because of the up-gradation of all the lower primary schools to the primary level in the year 2011. During up-gradation of lower primary schools to primary schools and other higher level the children below 5 years who were studying in pre primary, lower primary government schools were shifted to Integrated Child Development Centres (ICDCs)/ Anganwadi Centres.

\subsection{Number of Government Schools Teachers at Elementary Level}

The table and figure given below indicates the number of government schools teachers at elementary level in the State of Sikkim.

Table 2. Number of government schools teachers at elementary level.

\begin{tabular}{|c|c|c|c|c|c|c|c|c|c|}
\hline \multirow{2}{*}{ Districts } & \multicolumn{3}{|c|}{ Primary Level } & \multicolumn{3}{|c|}{ Upper Primary Level } & \multicolumn{3}{|c|}{ Elementary Level } \\
\hline & Male & Female & Total & Male & Female & Total & Male & Female & Total \\
\hline East & 831 & 952 & 1823 & 542 & 499 & 1041 & 1373 & 1451 & 2824 \\
\hline West & 854 & 545 & 1399 & 378 & 201 & 579 & 1232 & 746 & 1978 \\
\hline North & 257 & 179 & 436 & 114 & 88 & 202 & 371 & 267 & 638 \\
\hline South & 739 & 589 & 1328 & 357 & 245 & 602 & 1096 & 834 & 1930 \\
\hline State & 2681 & 2265 & 4986 & 1391 & 1033 & 2424 & 4072 & 3298 & 7370 \\
\hline
\end{tabular}

Source: Unified-District Information System for Education (UDISE, 2012-2013).

\subsection{Growth in Number of Government Schools Teachers at Elementary Level in Sikkim as on 2012-2013}

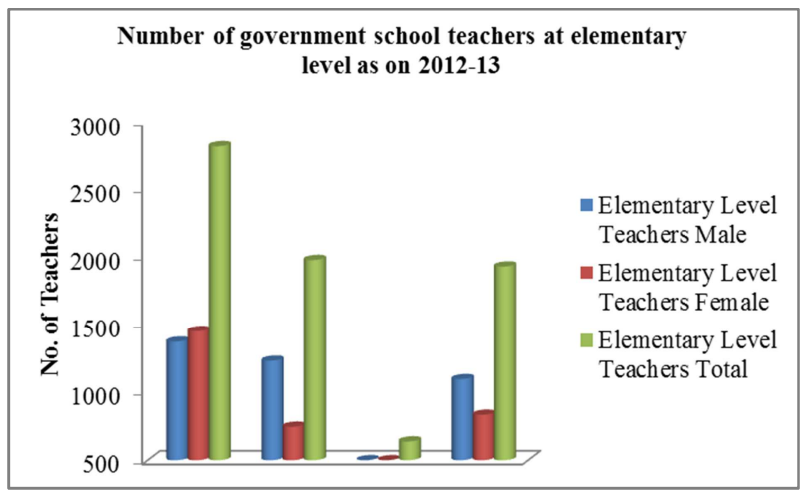

Figure 2. No. of government schools teachers at elementary level.

The above Table 2 and Figure 2 depicts that male teachers are appointed $53 \%$ and the female teachers are $45 \%$ it shows that the male teachers are more than female teachers at primary level and in the upper primary level male teachers are appointed $57 \%$ and the female teachers are $46 \%$ it indicates that the male teachers are appointed in a more numbers whereas, female teachers are less. Similarly, in both levels the male teachers are appointed $55 \%$ and the female teachers are $44 \%$, most of commission of education like Hunter commission 1886, Mudaliar commission 1982-83, Kothari commission 1964-66 has stressed on appointing female teachers especially for teaching girls students and primary school students due to psychological reasons, however Sikkim has not followed the recommendations.

\subsection{Enrolment of Students in Government Schools at Elementary Level}

The given below table and figure are the enrolments of students in government schools at elementary level in the State of Sikkim from the year 2009 to 2014: 
Table 3. Enrolment of students in government schools at elementary level (2009-2014).

\begin{tabular}{lllll}
\hline Type/Level of Institutions & $\mathbf{2 0 0 9 - 2 0 1 0}$ & $\mathbf{2 0 1 0 - 2 0 1 1}$ & $\mathbf{2 0 1 2 - 2 0 1 3}$ & $\mathbf{2 0 1 3 - 2 0 1 4}$ \\
\hline Pre-Primary & 12654 & N.A & N.A & 2690 \\
Primary & 61285 & 87123 & 69107 & 59704 \\
Junior High Schools (UP) & 26543 & 37263 & 45124 & 45958 \\
Total & 100482 & 124386 & 114231 & 108352 \\
\hline
\end{tabular}

Source: Annual Report, Human Resource Development Department, Government of Sikkim, Planning and Monitoring Evaluation Cell Note: UP (Upper-Primary Schools), NA (Not Applicable).

\subsection{Growth in Number of Government Schools Students at Elementary Level in Sikkim from the Year 2009-2014}

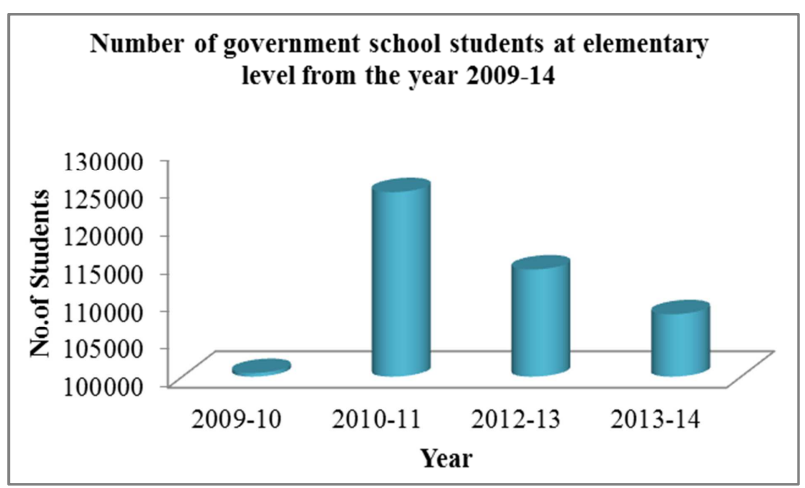

Figure 3. No. of government schools students at elementary level.

It is vident from the above Table 3 and Figure 3 that the enrolment was 12654 at pre-primary level in the year 20092010 , it is also revealed that the enrolment of pre-primary level went down in the year 2013-2014 to 2690, where as 61285 students enrolled at primary level in the year 20092010, which was increased by 69107 students in the year 2012-2013, and another 26543 students enrolled at junior high schools level in the year 2009-2010, which is again increased to 45958 students in the year 2013-2014. The total numbers of students enrolled were 100482 in the year 2009-2010 which is further increased to 114231 in the year 2012-2013. Being asked for the reason of decreased of number of students from 2010 to 2014. The Deputy Director, Sarva Shiksha Abhiyan (SSA), Government of Sikkim stated that the enrolment of pre primary students were decreased in the year 2010 to 2013 as all the government lower primary schools children were shifted to Integrated Child Development Centres (ICDCs) / Anganwadi Centres. Further it is also stated that less birth rate were recorded in this year and no admission took place in pre primary level. In the year 2013, pre primary classes started in government schools as there was a demand from public, so the admission took place. In the year 2016, the State Government of Sikkim placed a policy to provide pre primary education in the Montessori model. So Lower Kindergarten (LKG) and Upper Kindergarten (UKG) for pre primary level have been functioning in all the government schools. The objective of this decision was to provide quality education right from pre primary level and nurture them as well as prepared them for the higher classes in the government schools itself. According to record available in Human Resource Development Department, Government of Sikkim has started Lower Kindergarten (LKG) and Upper Kindergarten (UKG) at the pre primary level in all the government schools in the State.

\subsection{Administration and Decisions Made}

Administration in the State of Sikkim is under of Ministry of Human Resource Development Department (HRDD), Government of Sikkim. The Ministry is supported by secretariat level of Education which is further supported by level of Directorate of School Education. The Elementary Education is taken care by Director of School Education.

\subsubsection{School Land}

Table 4. School Land Registered.

\begin{tabular}{lll}
\hline \multirow{3}{*}{ School land registered } & Yes & No \\
\cline { 2 - 3 } & Frequency $(\%)$ & Frequency $(\%)$ \\
& $195(97.5)$ & $5(2.5)$ \\
\hline
\end{tabular}

The above Table 4 shows that 97.5 percent of the school land is registered in the name of schools and the remaining 2.5 percent of the school land is not registered in the name of school.

\subsubsection{Administrative Records}

Table 5. School Administrative Record.

\begin{tabular}{lll}
\hline & Yes & No \\
\hline & Frequency (\%) & Frequency (\%) \\
\hline Right after the establishment & $107(53.5)$ & $93(46.5)$ \\
Overall performance of the students & $200(100)$ & 0 \\
\hline
\end{tabular}

It is observed from the above Table 5 that 53.5 percent schools are keeping the administrative record right after the establishment, 100 percent schools have kept overall performance of the students. It shows that the headmasters were aware about the need of keeping records right after the establishment of the schools which may help to see the overall picture of the school and it may provide feedback to the school. According to Right to Education Act 2009 maintenance of records of children up to the age of fourteen years residing within its jurisdiction in such manner may be prescribed. However 46.5 percent were still not keeping administrative record at the time of establishment of schools. There should be training for the Head of the Department of schools to keep administrative records. 


\subsubsection{Appointment of Teachers}

The eligibility criteria for lower primary and primary teachers are class XII passed with Diploma in Elementary Education (D.EL.ED), District Institute of Education and Training (DIETs), Teacher Training Institute (TTI) selection on the basis of marks obtained in Teacher Eligibility Test (TET) and for upper primary (Elementary Level) teachers are Bachelor of Arts/ Bachelor of Science with B.ED and selection on the basis of marks obtained in Teacher Eligibility Test (TET). The selections of teachers have done on the basis of written test and viva voice.

\subsubsection{Norms Followed for Admission of Students}

Right to Education Act, 2009 no child shall be denied of admission in a school for lack of age proof and a child shall be admitted to a school at the commencement of the academic year or within such extended period as may be prescribed, provided that no child shall be denied of admission if such admission is sought subsequent to the extended period. Keeping in view all the government schools follow Right to Education Act, 2009 which advocates for free and compulsory education upto 14 years. Each student requires age proof followed by certificate of last exam passed, birth certificate is mandatory without fees. As per RTE Act the students are given admission throughout the year without any screening procedure. Preference is given to the local students and for class I admission, age of the child must be five (5) years and 6 years.

\subsubsection{Incentives}

Table 6. Incentives provided to students in government schools at elementary level.

\begin{tabular}{ll}
\hline Free text book & Frequency (\%) \\
\cline { 2 - 2 } & $\mathbf{2 0 0}(\mathbf{1 0 0})$ \\
\hline Free school uniforms, rain coats, bags, shoes, socks, exercise copies & $200(100)$ \\
\hline
\end{tabular}

It is revealed from the Table 6 that 100 percent of the headmasters reported that children enrolled at elementary level gets free text books, free school uniforms, rain coats, bags, shoes and socks, and exercise copies up to the primary level. Further text books and exercise copies for the students of class VI-VIII. 62.5 percent of the headmasters responded that the girls especially Scheduled Tribe (ST), and Scheduled Caste (SC) children received the scholarship from the department of education which has now been stopped since last few years. According to Sarva Shiksha Abhiyan (SSA) focus group children like Scheduled Tribe (ST), Scheduled Caste (SC) and girls are provided special incentives under Sarva Shiksha Abhiyan. However 37.5 percent of the headmasters responded that they have not yet received any scholarships for Scheduled Tribe (ST), Scheduled Caste (SC) and girls. On being interviewed the parents are not aware of scholarships to be received by their wards Scheduled Tribe (ST), Scheduled Caste (SC) and girls. The parents are not aware of scheme of Sarva Shiksha Abhiyan (SSA) which recommends to provide scholarships for Scheduled Tribe (ST), Scheduled Caste (SC) and girls. This shows that there is no demand from the public or civil society for proper implementation of centrally sponsored schemes.

\subsubsection{School Management Committee}

Table 7. School Management Committee.

\begin{tabular}{ll}
\hline School management committee & Frequency (\%) \\
\hline Members of SMC & $200(100)$ \\
Parent/ guardian & $192(96)$ \\
Teachers/Head teacher & $188(94)$ \\
Panchayat/ Senior citizen/ Academician & $187(93.5)$ \\
Women members & $178(89)$ \\
\hline
\end{tabular}

It is indicates from the Table 7 that the 100 percent of the headmasters reported that they have formed school management committee in the schools, while 96 percent of the headmasters affirm that parent/ guardian are the members of school management committee but 94 percent of the headmasters reported that it is teachers/head teachers, while 93.5 percent of the headmasters agreed that it is the panchayat/senior citizen/academician, whereas 89 percent of the headmasters responded that women members are the members of the school management committee in the State. As per Right to Education Act 2009 the school management committee at elementary level consists of the elected representative of the local authority, parents or guardians of the children admitted in the school. Keeping the point in view all the government schools in Sikkim follows RTE Act for functions of school management committee to function the schools in a smooth way.

\subsubsection{Library}

Table 8. Library in government schools at elementary level.

\begin{tabular}{lll}
\hline Library facilities in school & Yes & No \\
\hline School have library facilities & Frequency (\%) & Frequency (\%) \\
& $116(58)$ & $84(42)$ \\
& Yes & No \\
Separate room for library & Frequency (\%) & Frequency (\%) \\
& $59(29.5)$ & $141(70.5)$ \\
In-charge of the library & & Frequency (\%) \\
$\begin{array}{l}\text { A full time librarian } \\
\text { A teacher is in-charge to perform the duty of a librarian }\end{array}$ & $21(10.5)$ \\
\hline
\end{tabular}


The Table 8 shows that 58 percent of the headmasters affirm that schools have library facilities, 29.5 percent of the headmasters agreed that schools have separate rooms for libraries, 10.5 percent of the headmasters are of the opinion that schools have a full time librarian but 47.5 percent of the headmasters reported that it is the teacher who is in-charge of a librarian. Still 42 percent of the headmasters of elementary level schools stated that they do not have school library, while 70.5 percent of the headmasters agreed they do not have separate room for libraries in the schools. It is a matter of concern almost all the schools needs establishment of library room for reading purpose, it improves the quality of education; library promotes reading habits, students get access to books other than text books especially from the rural areas and they get opportunity to get read books with information which are not find in text books.

\subsubsection{Information and Communication Technology}

Table 9. Information and communication technology in government schools at elementary level.

\begin{tabular}{lll}
\hline \multirow{2}{*}{ ICT facilities in schools } & Yes & No \\
\cline { 2 - 3 } & Frequency (\%) & Frequency (\%) \\
\cline { 2 - 3 } & $\mathbf{1 3 5}(\mathbf{6 7 . 5 )}$ & $\mathbf{6 5}(\mathbf{3 2 . 5})$ \\
\hline Following are the ICT facilities in & Frequency (\%) \\
school & $80(40)$ & \\
Computer & $15(7.5)$ & \\
Over head projector & $13(6.5)$ & \\
Television & $11(5.5)$ & \\
Tape recorder & $16(8)$ & \\
Radio & & \\
\hline
\end{tabular}

The above Table 9 dipicts that 67.5 percent of the headmasters responded that school have facilities for Information and communication technology in the school, of which 40 percent of the headmasters asserted that computers, whereas 7.5 percent of the headmasters responded that schools have head projector, but 6.5 percent headmasters reported that schools have televisions, the other 5.5 percent of the headmasters are of the opiniontape recorder, another 8 percent of the headmasters stated that schools have radio. However 32.5 percent of the headmasters agreed that there is no information and communication technology (ICT) in the schools.

\subsubsection{Mid-day Meal}

Table 10. Mid-Day Meal in government schools at elementary level.

\begin{tabular}{ll}
\hline Mid-Day Meal in government schools & Frequency (\%) \\
\hline MDM supplied on time & $200(100)$ \\
Provide cooked food & $200(100)$ \\
$\begin{array}{l}\text { Specified menu of MDM given by the Human } \\
\text { Resource Development Department }\end{array}$ & $200(100)$ \\
Prepared as per the menu & $167(83.5)$ \\
\hline
\end{tabular}

It is indicates from the above Table 10 that 100 percent of the headmasters responded that supply mid day meal on time in the school, 100 percent of the headmasters stated that they provide cooked food, 73 percent of the headmasters reported that they provide food according to the specified menu of the mid day meal given by the Human Resource Development Department, Government of Sikkim, and another 83.5 percent of the headmasters asserted that they prepared food as per menu. However 16.5 percent of the headmasters said that mid day meal is not provided as per the menu. On being interviewed, 16.5 percent of the headmasters have expressed that difficult to manage according to specified menu; funds for mid day meal are not given on time. It is appreciable that at least cooked meals are provided to the children of elementary level schools in Sikkim as recommended by Sarva Shiksha Abhiyan and Right to Education Act, 2009.

\subsection{Infrastructural Facilities}

\subsubsection{School Building}

Table 11. School building of government schools at elementary level.

\begin{tabular}{lll}
\hline \multirow{2}{*}{$\begin{array}{l}\text { School building well equipped and } \\
\text { well maintained }\end{array}$} & Yes & No \\
\cline { 2 - 3 } & Frequency (\%) & Frequency (\%) \\
& $116(58)$ & $84(42)$ \\
\hline
\end{tabular}

The Table 11 showed that 58 percent of the headmasters responded that the school buildings are well equipped and well maintained. According to Right to Education Act, 2009 recommends for provision of infrastructure including school building, teaching staff and learning materials. The data shows still 42 percent of the headmasters mentioned that school buildings are ill equipped and need repairing or new construction. The reasons for not unequipped and maintained school:

(i) There is no planning as per the land of the school buildings are not properly build, so during rainy season there is a leakage problem. No ramps can be installed for children with special needs.

(ii) There is delay of construction work of new building and inadequate of class rooms and toilets.

(iii) There is no electrification and fencing, around the school.

(iv) There is no timely repairing of school.

\subsubsection{Staff Quarter}

Table 12. Staff Quarter in government schools at elementary level.

\begin{tabular}{lll}
\hline & Yes & No \\
\cline { 2 - 3 } Staff quarter in the school & Frequency (\%) & Frequency (\%) \\
\cline { 2 - 3 } & $\mathbf{1 1 ( 5 . 5 )}$ & $\mathbf{1 8 9}(\mathbf{9 4 . 5 )}$ \\
\hline If yes, & Frequency (\%) \\
Headmaster/Headmistress quarter & $7(3.5)$ & \\
Teaching staff & $4(2)$ & \\
Non-teaching staff & 0 & \\
\hline
\end{tabular}

It is revealed from the above Table 12 that 5.5 percent of the headmasters reported that schools have staff quarter in school, while 3.5 percent of the headmasters are of the opinion that there are headmaster/headmistress quarter, another 2 percent of the headmasters responded that teachers have teaching staff quarter. Furthermore none of the government schools till 
elementary level have non-teaching staff quarter in the State. It is observed that 94.5 percent of government schools till elementary level do not provide staff quater. None of the nonteaching staff have quarter, not even for chowkidars and peons of the schools. On inquiry further it was explained that some teachers stay in rented house, most of the teachers are locals, so they do not require quarter and they travel either in taxi or own vehicles for short distance.

\subsubsection{School Compound}

Table 13. School Compound in government schools.

\begin{tabular}{lll}
\hline \multirow{2}{*}{$\begin{array}{l}\text { School have a separate } \\
\text { compound }\end{array}$} & Yes & No \\
\cline { 2 - 3 } & Frequency (\%) & Frequency (\%) \\
\cline { 2 - 3 } & $\mathbf{1 3 7 ( 6 7 )}$ & $\mathbf{6 6}(\mathbf{3 3})$ \\
\hline $\begin{array}{l}\text { School area big enough for } \\
\text { conducting various }\end{array}$ & Yes & No \\
recreational activities & Frequency (\%) & Frequency (\%) \\
\hline
\end{tabular}

It can be seen from the above Table 13 that from the present study 67 percent of the teachers reported that schools have a separate compound. However 33 percent of the teachers responded that they do not have separate school compound which means that there is no fencing and hence it is open. While 46.5 percent teachers stated that schools area are big enough for conducting various recreational activities. This condition is difficult for schools which are basically established in urban areas, in such case there is possibility of public interference and there are chances of trespassing in the area of the school during its functioning and hence it may disturb the normal functioning of the school.

\subsubsection{Play Ground}

Table 14. Play ground in government schools at elementary level.

\begin{tabular}{lll}
\hline \multirow{2}{*}{ School play ground } & Yes & No \\
\cline { 2 - 3 } & Frequency (\%) & Frequency (\%) \\
\cline { 2 - 3 } & $\mathbf{1 1 9 ( 5 9 . 5 )}$ & $\mathbf{8 1}(\mathbf{4 0 . 5 )}$ \\
\hline If yes, Location & Frequency (\%) \\
Outside the school premises & $21(10.5)$ & \\
Within school premises & $98(49)$ & \\
\hline
\end{tabular}

The Table 14 shows that 59.5 percent of the teachers affirm that schools have a play ground. However 40.5 percent of government schools do not have play ground. Furthermore 10.5 percent of the teachers agreed that location of the play ground is outside the school premises, but 49 percent of the teachers are of the opinion that it is within school premises.

\subsubsection{Class Rooms}

The Table 15 indicates that 82 percent of the headmasters responded that classrooms are well ventilated and lighted, while 55.5 percent of the headmasters stated that schools have sufficient furniture, another 68 percent of the headmasters agreed that they have sufficient number of tables and chairs, whereas 88 percent of the headmasters responded that schools have sufficient number blackboards, chalks, duster, the other 66 percent of the headmasters reported that schools have desks and benches, 31 percent of the headmasters agreed that schools have book self, while 1 percent of the headmasters affirm that school has resource room for children with special needs. However, still 44.5 percent of the headmasters stated that there is no sufficient furniture in the schools and they further stated that majority of the schools i.e., 99 percent do not have resource rooms for Children with Special Needs in the State.

Table 15. Class rooms in government schools at elementary level.

\begin{tabular}{|c|c|c|}
\hline \multirow{3}{*}{$\begin{array}{l}\text { Classrooms well ventilated } \\
\text { and lighted }\end{array}$} & Yes & No \\
\hline & Frequency (\%) & Frequency (\%) \\
\hline & $164(82)$ & $36(18)$ \\
\hline \multirow{3}{*}{ Sufficient furniture } & Yes & No \\
\hline & Frequency $(\%)$ & Frequency $(\%)$ \\
\hline & $111(55.5)$ & $89(44.5)$ \\
\hline \multirow{3}{*}{ Table \& chair } & Yes & No \\
\hline & Frequency $(\%)$ & Frequency $(\%)$ \\
\hline & $136(68)$ & $64(32)$ \\
\hline \multirow{3}{*}{ Blackboards, chalks, duster } & Yes & No \\
\hline & Frequency $(\%)$ & Frequency $(\%)$ \\
\hline & $176(88)$ & $24(12)$ \\
\hline \multirow{3}{*}{ Desks \& benches } & Yes & No \\
\hline & Frequency $(\%)$ & Frequency $(\%)$ \\
\hline & $132(66)$ & $68(34)$ \\
\hline \multirow{3}{*}{ Book self } & Yes & No \\
\hline & Frequency $(\%)$ & Frequency $(\%)$ \\
\hline & $62(31)$ & $138(69)$ \\
\hline \multirow{3}{*}{ Resource room for CWSN } & Yes & No \\
\hline & Frequency $(\%)$ & Frequency $(\%)$ \\
\hline & $2(1)$ & $198(99)$ \\
\hline
\end{tabular}

\subsubsection{Drinking Water, Toilets and Electricity Connections}

Table 16. Drinking water, toilets and electricity connections in government schools.

\begin{tabular}{lll}
\hline \multirow{2}{*}{$\begin{array}{l}\text { School have separate toilets for } \\
\text { teachers as well as students }\end{array}$} & Yes & No \\
\cline { 2 - 3 } & Frequency (\%) & Frequency (\%) \\
\cline { 2 - 3 } & $\mathbf{1 7 4}(\mathbf{8 7})$ & $\mathbf{2 6}(\mathbf{1 3})$ \\
\hline \multirow{2}{*}{ Separate toilet for the boys \& girls } & Yes & No \\
& Frequency (\%) & Frequency (\%) \\
& $160(80)$ & $40(20)$ \\
Safe drinking water in the school & Yes & No \\
& $147(73.5)$ & $53(26.5)$ \\
\multirow{2}{*}{ Electricity connection } & Yes & No \\
& Frequency (\%) & Frequency (\%) \\
\hline
\end{tabular}

The Table 16 evident that 87 percent of the headmasters stated that the schools have separate toilets for teachers as well as students, 87 percent of the headmasters reported that schools have separate toilet for the boys and girls, another 73.5 percent of the headmasters responded that safe drinking water is provided in the school. According to Sarva Shiksha Abhiyan (SSA) guidelines separate toilet for boys and girls is mandatory, still 13 percent of the schools do not have separate toilets for boys and girls. It is basic facilities that provide for good hygiene and privacy as well as it assists to 
promote enrolment of girl child in school and complete their education. Further 23.5 percent of the headmasters stated that schools do not have safe drinking water facilities in the school. Safe drinking water within the school premises is necessary, it promotes health and hygiene behaviour at early stage of childhood; improve the health of children in school. It may help all the children have the opportunity to go to a school with access to safe water and hygiene education. It is also revealed that 23.5 percent of the schools are managing by taping from neighbouring house and managing from nearest water source through temporary connection. 67 percent of the headmasters reported that schools have proper electricity connection in school. However 33 percent of the headmasters responded that schools do not have electricity connection in the school. It is important to have electricity connection in the school because it enables the use of modern mass media tools in the classroom such as the internet, computer and television. So that it may help to improve the quality education in the State.

\section{Problems at Elementary Level in the State of Sikkim}

(1) Like in any other State the system of Education in Sikkim is also based on education policy of the Nation. Interventions like Sarva Shiksha Abhiyan have been launched in the State of Sikkim in the year 2001. The objective of this intervention is to provide education to all children in the State by providing basic infrastructures. Nonetheless, the Elementary Education is not free from its shortcomings.

(2) The Elementary Education has problems of attracting good students at primary level which point at the problem of quality.

(3) There is lack of trained teachers who are the actual disseminators of knowledge.

(4) Recent appointments of the teachers are made on adhoc basis who are mostly not dedicated and looking for better opportunities. Such untrained and unmotivated teachers surely cannot provide quality education to students who need to build strong foundation of knowledge.

(5) Still most of the schools do not have adequate infrastructure for students.

(6) There is lack of playground for students who need to play and this lack leads to many physical illnesses.

(7) Almost all the elementary school do not have electricity connection which prevents teachers plan using modern devices like computer for teaching and management of schools.

(8) Some more problems are that there is unavailability of subject wise teachers for class VI to VIII.

(9) In Sikkim Continuous and Comprehensive Assessment is started in all the government schools in 2010. It is observed that none of the stakeholders have understood the concept of continuous and comprehensive and assessment. Human Resource Development Department (HRDD) started the programme without much plan and thought. At present teachers have taken it as an escapade, they think that they need not teach but give marks to students to pass. The present scenario of evaluation is not at all continuous and comprehensive. The students are awarded grades and promoted without continuous observation and assessment which will surely affect the quality of education as well as the products of the system.

(10) Over appointment in urban schools and fewer teachers appointed in rural schools.

(11) Teachers who are already appointed for long are not trained.

(12) Teachers who are trained through Certificate of Primary Education of IGNOU cannot be equalized with two years of course of DIET.

(13) Teachers from urban schools are called often for training leading to over training of few, whereas, teachers from rural areas are neglected.

(14) Though, the medium of instruction is English but majority of elementary schools teachers use translation method to teach from English to Nepali.

(15) It is observed that the fund given by SSA do not reach schools like teachers grant for teachers.

(16) Some of the schools still do not have toilets and drinking water facilities.

(17) Some of the school buildings in rural areas are in dilapidated condition.

(18) Most of the schools do not have proper fencing around the schools.

\section{Discussions}

The study showed that number of schools has been upgraded to the higher level like pre-primary to primary, primary to junior high school, junior high school to secondary school, secondary school to senior secondary school. It means that the result indicates that the positive scenario in the State. State government should also construct new school buildings with adequate infrastructure.

The data shows that the highest numbers of male teachers are appointed in both levels i.e., primary and upper primary as compared to female teachers. But most of commission of education like Hunter commission 1886, Mudaliar commission 1982-83, Kothari commission 1964-66 has stressed on appointing female teachers especially for teaching girls students and primary school students due to psychological reasons.

With regard to enrolment of students in government schools at elementary level, the number of students has been decreased though the Central and State government has provided various incentives like free uniforms, exercise copy, shoes, rain coat and mid day meal for the children who have been enrolled at elementary level. A similar finding was also revealed by Nangia (2013), that overall decline in the enrolment at primary 
level. However, the findings contradict the findings of Kumari and Makkar (2012), found that the number of students enrolment at elementary has been continuously increased.

It is revealed from the present study that majority of the government schools land has registered in the name of school. With regards to administrative record it was found that administrative records have kept and it is also observed that majority of schools have kept overall performance of students.

The eligibility criteria for appointing primary teachers are class XII passed with Diploma in Elementary Education (D.EL.ED), District Institute of Education and Training (DIETs), Teacher Training Institute (TTI) selection on the basis of marks obtained in Teacher Eligibility Test (TET) and for upper primary (Elementary Level) teachers are Bachelor of Arts/ Bachelor of Science with B.ED and selection on the basis of marks obtained in Teacher Eligibility Test (TET). It shows that from the present study the Human Resource Development Department, Government of Sikkim has fulfilled all the criteria for appointing the elementary level teachers in the State.

From the present study it is indicates that as per Right to Education Act, 2009 the students are given admission throughout the year without any screening procedure in the State.

The findings of the present study revealed that majority of the headmaster agreed that children enrolled at elementary level gets free text books, free school uniforms, rain coats, bags, shoes and socks and exercise copies up to primary level. Further text books and exercise copies for the students of class VI-VIII. However it was found from the present study that scholarships for Scheduled Tribe (ST), Scheduled caste (SC) and girls were not given which is recommended by Sarva Shiksha Abhiyan.

It was found from the present study that majority of the schools have school management committee. It shows that all the government schools at elementary level follows RTE Act for functions of school management committee to function the schools in a smooth way.

Further the present study revealed that the most of the government schools at elementary level library facilities are not available. In some schools there is no information and communication technology facility (ICT) in the schools. A similar finding also indicates by Jain and Agarwal (2011), that ICT facilities like radio, tape recorder, television and over head projector are not available in the State of Assam.

The findings of the present study indicates that all the government schools at elementary level provides cooked mid day meal for the children. A similar finding was put forwarded by Singh and Mishra (2010).

It was found that majority of the schools have well equipped and well maintained school building and other facilities like separate school compound, play ground, classrooms, drinking water, toilets and electricity connections. However facilities like staff quarter are not available in the government schools at elementary level. The findings of the Kumar, Kumar and Narula (2011) contradicts the lack of infrastructure at elementary level of education and the condition is more shocking in rural areas however enrolment is increased and dropout is declined. Infrastructure element such as availability of toilets, electricity, book bank and computer is very feeble. A similar finding was made by Zaidi (2008).

\section{Recommendations}

(1) State should have separate directorate for elementary education. It may help to improve the status of elementary schools.

(2) For the improvement of elementary education there should be pucca school building with sufficient furniture, lab equipment and adequate teaching staff.

(3) The school should have properly maintained infrastructure. The library and laboratory facilities in the school. So that it can be improve the quality of education in the State.

(4) There should be school playground within the school premises. It can be benefit for wholesome development of children.

(5) Appointment of teachers as per subject wise rather than general subject teacher.

(6) Trained teachers such as sports, music, and arts should be appointed to fulfil the objectives of continuous and comprehensive assessment.

(7) Primary level teachers should be well trained and should get every facility of new methods of teaching and learning equipments.

(8) Abolish Adhoc system of appointment.

(9) Syllabus of textbooks should be related with real life and the curriculum should also be updated from time to time.

(10) Medium of instruction should always be followed in English with students this is one language which being together students from different mother tongue and it includes students with different language background. So that they can improve their speaking skills which will definitely improve their personality.

(11) Human Resource Development Department, Government of Sikkim should provide sufficient funds like school grants, ancillary and stationary grant in time.

(12) It is necessary to have separate toilets for boys and girls. So that it can be help to increase the enrolment of students in the government schools in the State.

(13) Safe drinking water facilities should be provided within the school compound.

(14) The school buildings should be repaired in time to create a congenial environment.

(15) Schools should have proper fencing to control trespass.

\section{Implications of the Study}

Based on the findings, the following implications are useful for the policy makers, teachers, and school administrators of government schools at elementary level in the State of Sikkim. 
(1) The findings of the present study will be helpful for the education policy makers in the State of Sikkim. It was observed that the number of government school has decreased, the less number of female teachers has been appointed and the number of students has also decreased at elementary level in the State. Thus, there should be educational policy in the state to appoint at 33 percent of female teachers, establish elementary school within one kilometre in a habitat as per Sarva Shiksha Abhiyan (SSA) guidelines.

(2) The study will be useful to the Human Resource Development Department, which is the parent department in the state to look after the education. It gives them overview of the elementary education. There is a need of improving infrastructure in the elementary level schools. It is necessary to provide library with librarian and establish laboratory so that experiential and constructive learning takes place.

(3) The findings of the study will be helpful for the teachers and head teachers for the need of improving elementary education in the state through proper use of Information and Communication Technology. The government schools may create congenial environment in the school to make learning fun for elementary students thereby bringing up quality education among the children.

(4) The findings of the study provide status of elementary education to the civil society. Since many of them are the members of the school management committee, they may provide suggestions or assistance to the particular school. People of the state will become aware about the elementary education which is the foundation of education system.

\section{Conclusion}

It is revealed from the present study that the numbers of government schools have increased for the last six years as well as some schools are upgraded to the higher level i.e., pre primary to primary, primary to junior high school, secondary school and senior secondary school in the State. However the numbers of students have decreased in the government schools at elementary level. It is felt that matter should be looked seriously by the Human Resource Development Department, Government of Sikkim, so it can be improve in the enrolment rate of students in the government schools at elementary level. There is need to provide adequate infrastructure like chairs, tables, safe drinking water, separate toilets for boys and girls, computer, for Information and communication technology, Internet connection. Trained teachers especially in rural areas as it has been observed that most of the teachers are centred in the schools in the urban areas and the schools in rural areas have inadequate numbers of teachers. Continuous and comprehensive assessment is followed for assessment of students in government schools but it seems not improved due to lack of proper training of teachers on continuous and comprehensive assessment and inadequate number of teachers. Since examination and assessment are important component of education system of the teachers of elementary should be provided hands on training through the workshop instead of lectures and seminars as well each elementary school should have adequate number of teachers to fulfil the objectives of continuous and comprehensive assessment. The Government of Sikkim has attempted to bring quality of education in the government schools by providing various incentives like free uniforms, text books, exercise copy, shoes, bags and raincoats for primary level children (Class I-V) and text books and exercise copy for upper primary level students (Class VI -VIII). The government also provide various scholarships like chief minister's merit scholarship and Prerna scholarship for those Class V students who get selected in competitive State level examination. Such scholarships encourage the meritorious students from rural areas, which in turn help in prepare a good citizen. The government of Sikkim has started Montessori Model of education at pre primary level in the government schools which provides Lower Kindergarten and Upper Kindergarten system of education, to bring the quality of education among the children. The elementary education growth lays a foundation for other higher level of education. Adequate attention of governmental policies and facilities are required to strengthen the foundation of whole education system.

\section{References}

[1] Human Resource Development Department, Planing and Monitoring Evaluation Cell. (2001-2014). Annual Report. Gangtok: Government of Sikkim.

[2] Human Resource Development Department, Planing and Monitoring Evaluation Cell. (2003-2004). Annual Report. Gangtok: Government of Sikkim.

[3] Kharel, S., \& Bhutia, J. W. (2013). Gazetteer of Sikkim. Gangtok: Government of Sikkim, Home Department.

[4] Jain, V K., and Agrawal, Mamta. (2011). Resources in Primary Schools: A Challenge for India. Indian Educational Review 48 (1), 86-92.

[5] Kumar, Vipan. Kumar, Naresh., and Narula, Sapna. (2011). Mapping of Elementary Educational Infrastructure in India: A State and District level Analysis. International Journal of Multidisciplinary Research (I). Retrieved from $</$ http://knowgate.niscair.res.in/>

[6] Kumari, Sharmila., and Makkar, Renu. (2012). Education Sector in India: A Case Study of Elementary Education. International Referred Research Journal III (37). Retrieved from $</$ www.ssmrae.com $/>$.

[7] Nangia, Anita. (2013). Enrolment in Govt Schools of U. T., Chandigarh. International Indexed and Referred Research Journal, ISSN-0974-2832, 51-52.

[8] Srivastava, D. S., \& Tomar, Monica. (2011). Elementary Education. New Delhi: Isha Books. 
[9] Seventh All India School Education Survey. (2002). State Reports of Sikkim. Gangtok: Government of Sikkim, Human Resource Development Department.

[10] Sharma, M. (2010). Research Methodology, Assignment, Seminar Paper \& Project. Guwahati: EBH Publisher.

[11] Singh, Manju and Mishra, Niharranjan. (2010). Evaluation Study on Mid Day Meal Programme in Meghalaya. Retrieved from Council for Social Development, Southern Regional Centre Hyderabad: Rajendranagar, website: </ megpied.gov.in/>.
[12] Thamarasseri, Ismail. (2008). Early Childhood and Elementary Education. New Delhi: Kanishka Publishers.

[13] Unified-District Information System for Education (UDISE). (2012-13). School Report Cards. Retrieved from www.udise.in.

[14] Zaidi, S. M. I. A. (2008). Facilities in Primary and Upper Primary Schools in India. New Delhi: NIEPA. Retrieved from $</$ www.ncert.nic.in/>. 